\title{
Perceived Benefits and Drawbacks of the Retirement Age Policy in Malaysia: HR Perspective
}

\author{
Lai Cheng Tung ${ }^{1} \&$ Jean Dennis Comeau ${ }^{2}$ \\ ${ }^{1}$ School of Business \& Administration, Wawasan Open University, Penang, Malaysia \\ ${ }^{2}$ American Degree Programme, SEGi College, Penang, Malaysia \\ Correspondence: Lai Cheng Tung, School of Business \& Administration, Wawasan Open University, 54 Jalan \\ Sultan Ahmad Shah, 10050 Penang, Malaysia. Tel: 60-4-218-0431. E-mail: lctung@wou.edu.my
}

Received: July 19, 2012 Accepted: August 29, 2012 Online Published: October 1, 2012

doi:10.5539/ijbm.v7n19p1 URL: http://dx.doi.org/10.5539/ijbm.v7n19p1

\begin{abstract}
Continuing improvements in life expectancy means that people will live longer on average than any previous generation. The combination of increased life expectancy and new retirement age policy in Malaysia has important implications for human resource management. Recently, the Ministry of Human Resource of Malaysia proposed a bill to increase the retirement age in the private sector to 60 years which has resulted in a swirling debate. This has raised many arguments implying demographic, economic, social and political points of view; both in favour of, and against the proposed policy. Malaysia has been slower in taking steps to increase the retirement age as compared to neighbouring ASEAN countries. According to the International Institute of Management, there are a number of countries with higher retirement ages which are ranked higher than Malaysia in terms of productivity and economic scale. It is imperative to study the implications of the proposed new policy from the aspect of human resources. In this study, an open-ended survey of 230 currently employed individuals of varying demographics was conducted in a number of cities across Malaysia (Kuala Lumpur, Penang, Ipoh, Kuching Kota Bharu and Johor Bharu) to determine reactions and opinions about the imminent retirement age policy changes. The collected qualitative data was analysed for the emerging key themes using a coding method. The data was analysed by reading through more than 230 scripts, sorting the opinions into specific response categories and grouping common themes and repeated words and phrases. Although the findings suggested that most of the respondents (86\%) agreed to raise retirement age policy, some remains skeptical (14\%). Among the positive points stated by the respondents are the contribution to the nation growth, ensure financial security, reduce reliance on foreign labours, mental and physical fulfillment for older workers. The majors perceived drawbacks among respondents are on the issues of potentially reduce job opportunity, career advancement for younger workers, low productivity and higher cost compare to younger employees. Findings of this study could provide better understanding regarding the spectrum of opinions regarding the policy of increasing the retirement age in Malaysia as well as other nations, especially in the private sector.
\end{abstract}

Keywords: retirement age policies, older workers, human resource management, Malaysia policy

\section{Introduction}

Retirement can be defined as the period when an individual stops employment completely and begins a new phase of life. It is estimated that on average, every day, there are 12,000 baby boomers turning 50. Many social and employee benefit policies were designed for an era when people had shorter life expectancy and employers had a large cohort of younger workers to replace those retiring (Turner, 2008). However, this scenario has changed over the past decade. According to vital statistics from Malaysia's Department of Statistics; in 2010, the average life expectancy in Malaysia has risen to 71.7 years for males and 76.6 for females (Department of Statistics Malaysia, August 2010). According to the US Central Intelligence Agency's World Factbook (2012), the present Malaysian life expectancy is the third highest in the Southeast Asian region following after Brunei (76 years) and Singapore ( 82 years), respectively. Life expectancy is defined as the statistical measure of average age that a group of people would be expected to live based on IRS issued by each country. Modern advanced healthcare development and continuing improvements in life expectancy, means that people will live longer on average than any previous generation. Increases in life expectancy have indirectly resulted in a large increase in the expected years an individual will spend in retirement. According to the HSBC's The Future of Retirement 
report (2011), perceptions of retirement are changing in the East and West as people live longer. There has been a significant shift in retirement age policy and many more people are expressing fears of financial hardship, now, compared to that of their parents. The Future of Retirement programme questioned over 17,000 people in 17 countries about retirement and financial planning as part of its drive to better understand the trends and consequences of aging and retirement. Sixty nine percent of the Malaysians in the study are optimistic about their retirement, mostly associating freedom with their retirement, and 84 percent said they have begun to plan for their retirement. The findings of the study also revealed that Malaysia has the earliest (lowest) national retirement age requirement, at 55 years old, among the Southeast Asian nations surveyed. Hong Kong and Taiwan have highest the national retirement age at 65 years old followed by Singapore at 62 . South Korea, China and India have gradually lifted the retirement age requirement to 60 to help cut costs and in recognition of improved life expectancies. An interesting fact from the study revealed that amongst the Malaysians surveyed, a majority of them anticipated to retired at the age of 58, which is beyond the national requirement of 55 .

Virtually all countries, Western and Eastern, alike are seeking to bring retirement ages more in line with the increases in life expectancy (Appelbaum, Patton and Shapiro, 2003; HSBC's The Future of Retirement report, 2011; Turner, 2008). Looking toward the future and global economic downfall, policies emphasizing "on time" or early retirement will soon become obsolete. Human resource policies in many countries (organisations, alike) used to encourage "on time" or early retirement out of social and economic necessity. One example would be encouraging retirement of older workers as an alternative to layoffs during economic downturns (Appelbaum, Patton and Shapiro, 2003). In responding to the increased life expectancy, the Malaysian government has raised the public and civil servant retirement age to a mandatory 58 , however, the private sector has different schemes and requirements (myGovernement n.d.). Following the increased retirement age policy in the public and civil sectors, the Ministry of Human Resource of Malaysia recently proposed a bill to make 60 years of age the earliest retirement age for the private sector. The proposed Minimum Retirement Age Bill tabled by the Ministry of Human Resource would supersede any previous retirement age agreed between employers and employees if the bill is passed into law. Unlike in the public sector, the propose of the private sector bill is not a mandatory requirement that forces private sector employees to retire at a specific age, but, the bill states that employers who prematurely force workers to retire early would be liable to a fine of up to RM10,000 (Teoh, 2012). The new proposal of increasing the retirement age in the private sector to 60 has resulted in a swirling debate among private sector employees across Malaysia. This actions have raised many arguments implying demographic, economic, social and political points of view; both in favour of, and against the proposed change. The central question in the present paper is to highlight and provide insight and opinions among the private sector employers across Malaysia regarding the proposed retirement age policy from the perspective of human resources.

\section{Retirement in the 21st Century}

Rosen and Jerdee (1986) in their earlier study on retirement policies has contended that 21 st century retirement policies have to be flexible and adaptable in order to meet the ever changing social demographics and human capital shortages in certain occupations. This contention was based on the increasing life expectancies and that older employees are mentally and physically able to extend their working careers. Some might share the sentiment that they have 'plans to work right up to the day of their funeral'. This notion was echoed in views from another study by Turner (2008) and Appelbaum, Patton and Shapiro (2003) on older employees who are living longer and enjoying working longer than in the past.

The phenomenon of demographic shifts dramatically affected the retirement policies in Europe during the early 21 st century. Gendron (2011) said that the European nation is experiencing massive demographic shifts due to advancements in healthcare and decreases in fertility which has affected individuals, families, local communities and countries because the number of people over 60 years old is going to increase substantially. The author contended that the culture that encouraged early retirement in Europe since the 1970s might not be in the best interests of societies, given the current tight labour market. In France, for instance, in 1982 the legal retirement age was lowered from 60 with the introduction of solidarity contracts of early retirement (contrats de solidrité préretraite) offered to workers aged 55. The reasoning behind this was to give way to younger workers. However, the policies did not last long and were abandoned at the end of the 1980s due to an economic recession. In the mid-1990s, the French government introduced a scheme that offered a 'replacement allowance for employment or job substitution allowance' for older workers who had the possibility to receive full unemployment insurance benefits until the age of 60, in exchange for hiring a young unemployed worker. Again, the scheme did not last long as the costs of early retirement were too high, where at one point there were 705,000 beneficiaries. Studies showed the program was not sufficient to protect or induce employment of 
younger workers. The author noted that presently the retirement issues in Europe (especially in France) are still polarizing and there is ongoing debate between policy makers and the involved enterprises, he did offer that in the current tight labour market there must be an intergenerational bond where the older people transmit and the young people learn. To sum up, using an early exit strategy policy for older workers is not effective for getting younger workers into the workforce and comes with high societal costs.

In contrast Japan has had a different experience, where instead of encouraging early retirement, more preventive measures were taken to actively retain older workers in order to help them cope with the rising cost of living. Accordingly to Casey (1998), Japan is among the very high level of labour force participation of its older workers (in particularly older men) across Asia. As many as 37 percent of men aged between 60 and 65 are still in the labour force and all are economically active (still at work). Fujioka (2008) noted that Japan was the first to legislate re-employment in 2006 that was supposed to help the older workers. The author wrote that unlike Japan's traditional lifetime employment system, where employees were guaranteed promotions and pay increases as they grew older regardless of performance, the new legislation focused on performance-based management. After the legislation took effect, older workers were found to often switch jobs because of their unhappiness about how they were being evaluated under performance-based management. At the same time, younger workers in Japan have recently reported favouring carefree lifestyles of hopping between jobs and quitting as often as the older workers. This phenomenon has been a challenge for Japanese companies in coping with the present labour crunch.

To cope with longer life expectancy of Singaporeans, the Singapore Ministry of Manpower recently took the proactive step of introducing the "Retirement and Re-employment Act (RRA)" instead of merely raising retirement age beyond the current age of 62. According to the Singapore Ministry of Manpower press release website (Ministry of Manpower, 2011) just raising the retirement age may not be effective in reducing societal retirement costs. The RRA bill provides Singaporean employers and employees, the flexibility to make necessary adjustments to employment terms and conditions to meet their respective needs. This flexibility helps to allow older workers who are willing and able to continue working to do so beyond retirement and will provide flexibility to facilitate employers to retain their older workers beyond retirement (Ministry of Manpower, 2011).

\section{Survey Studies Gauging Perceptions towards Raising Retirement Age}

According to a survey conducted by JobStreet.com with 3,485 jobseekers in Malaysia of between 18 and 41 found out that $72 \%$ of its respondents are in favour of the increase in retirement age. Although the majority agreed to a raise in retirement age, there were some reservations about the effects of the implementation as well. Their study revealed that among the top reasons people were in favour of the new proposal were; feeling they required more retirement savings, increase of life expectancy, and that it allows retention of talent especially in professions that require years of experience. Conversely, the top reasons from respondents who disagreed with the raised retirement age were that older workers might be less productive, feeling that older workers should be enjoying their golden years and that there would be fewer job openings for graduates in the market if the older workers were still on the job. Perhaps it is not surprising that respondents who disagreed were mostly from the younger group (aged between 18 and 35 years). This survey showed that a minority of respondents (34\%) preferred the ideal retirement age be set at 60 years old. Fifteen percent $(15 \%)$ of the respondents preferred 65 years or over and $24 \%$ preferred the status quo of 55 years of age (Jobstreet.com, 2011).

In another survey, conducted by an independent consultant group, Aon Hewit, questioned 107 mixed industry companies to gauge employers' opinions about the government's initiatives regarding retirement age. Nearly half (about 45\%) of companies felt that the current retirement age is ideal and should be kept as is. Only $29 \%$ feel that there is a need to increase the retirement age and that it should be increased across the board. The rest of the companies $(17 \%)$ responded that they felt that it should be increased depending upon on the job functions and levels. One interesting finding was regarding whether mandatory retirement age should be imposed. The response was slip almost 50/50 in favor and against. Though Malaysia does not have a mandatory retirement age, companies have, in the past, set their retirement age to follow the civil service. Even though the public and civil service retirement age has since been revised to 58, many companies have yet to revise their retirement age accordingly to Aon Hewitt's survey. Only about $10 \%$ of companies have retirement age set at 56 and about another $10 \%$ at age 60 (HR Matters, 2012).

Similarly, a comprehensive retirement research report compiled by Brossard and Chatelet (2010) surveyed 1,037 Malaysian (as well 16,000 respondents across 26 countries, worldwide).The two groups surveyed were: (i) a working group aged 25 and above and (ii) retirees aged 45 and above. The survey studied the expectations and 
opinions about ideal retirement age. Their study revealed that the Malaysian working group much preferred to retire at age 56 while the retirees would opt to work until 57 years old rather than retire at age 55. Interestingly, in both groups, the younger they are the earlier they would like to retire according to the report. Nearly $60 \%$ of the Malaysian respondents would like to see the minimum legal age to retire raised. Most of the disapprovals come from the respondents from the east coast of Malaysian. Although Malaysian respondents have the highest approval on raising the retirement age, among the surveyed countries, it was also noted Malaysia has the earliest national retirement age requirement to begin with. Their survey findings also concluded that Western country's respondents are more reluctant to increase the retirement age compared to Asian respondents, partly due to the fact that the present retirement age in most Western countries has been lifted to 62 years or above.

Many surveyed Malaysian businesses would still prefer retirement age to be kept at 55 years old according to a survey report compiled by the Federation of Malaysian Manufacturers (FMM) and Malaysian Institute of Economic Research (MIER). In contrast to general public's opinion, only a minimum of Malaysian employers (about 28\%) would like to see the retirement age raised to 60 . Nearly $52 \%$ indicate the opposite saying the current age limit should be maintained. Unfortunately, the report did not detail out the reasons behind why respondents felt the way they did (Federation of Malaysian Manufacturers, 2012).

\section{Research Methodology}

The current study deals with collective opinions collected across Malaysia concerning the new proposed change to the retirement age policies tabled by the Malaysian' Ministry of Human Resource. In this study, an open-ended survey was collected from 230 employed individuals of varying demographics across five cities in Malaysia (namely Kuala Lumpur, Penang, Ipoh, Kuching Kota Bharu and Johor Bharu) in order to determine the reactions and opinions about the imminent retirement age policy changes. In order to record and analyse the results, the researchers used qualitative descriptive methodology in collecting the qualitative data. The data was analysed using a coding method. The data obtained from the 230 respondents was analyzed by sorting the opinions into specific response categories and grouping them into common themes and repeated words and phrases. Specifically, the detailed descriptions of the grouped responses are themed into four (4) dimensions as presented in Table 1:

Table 1. Four dimensions of concerns

\begin{tabular}{ll} 
Dimensions of Concerns & \multicolumn{1}{c}{ Descriptions } \\
\hline Demographically-Concerned & $\begin{array}{l}\text { The concern on dealing with human populations as a whole such } \\
\text { as regarding density, vital statistics on ageing, dispersion of } \\
\text { generations, etc. }\end{array}$ \\
& $\begin{array}{l}\text { The concern related to the management of income, expenses, } \\
\text { money or wealth. }\end{array}$ \\
Economically-Concerned & $\begin{array}{l}\text { Concerns pertaining to the life, welfare, and relations of human } \\
\text { beings in a community. } \\
\text { Concerns with regard to social relationships and responsibility } \\
\text { Politically-Concerned }\end{array}$ \\
& involving authority (government).
\end{tabular}

A conceptual framework of this study was developed in order better illustration of the model used for this study. Miles and Huberman (1994) noted that the conceptual framework serves several purposes: (a) identifying who will and will not be included in the study; (b) describing what relationships may be present based on logic, theory and/or experience; and (c) providing the researcher with the opportunity to gather general constructs into intellectual "bins" (Miles \& Huberman, p. 18). The conceptual framework serves as an anchor for the study. The framework was based on the literature and the researchers' personal experiences. The major constructs are contained in the following manner as Figure 1: 


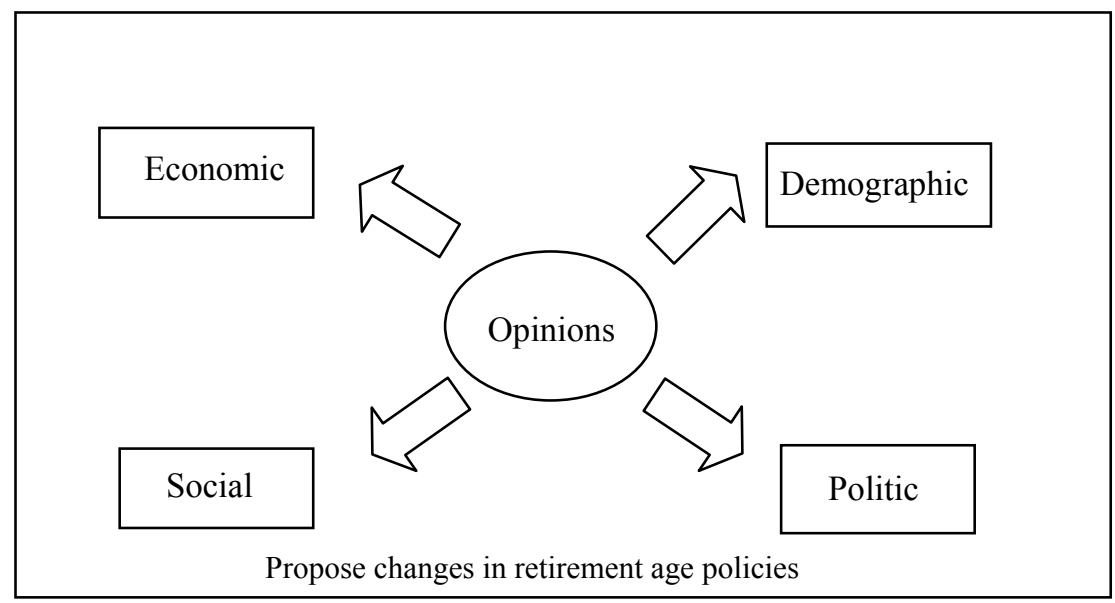

Figure 1. Theoretical framework of the major constructs

In addition to qualitative data, some quantitative data was also collected regarding (i) age groups, (ii) regional centres and (iii) opinions about the proposed changes towards the new retirement policies. Beehr (1986) contended that to develop well-inclusive retirement policies, accurate information is needed about the perceptions and intentions of people who will be affected when the bill passes into law. To explore the issues of retirement age policies, the following questions were investigated and analysed based on the collected data:

1. What are the perceived reactions towards the proposed retirement age increase to 60 years (agree or disagree)?

2. What do respondents perceive as the benefits and drawbacks for themselves as they look ahead toward retirement?

3. What are the implications from the Human Resource perspective?

\section{Results/ Findings}

Table 2 shows the descriptive statistics of the profile of surveyed respondents. Of 230 surveyed respondents, about 32 percent were in the $21-30$ age category, 64 percent were in the $31-49$ age category, and only 4 percent were age 50 or above. Breaking the sample down according to the five cities centres across Malaysia, the largest sample came from Penang which recorded 68 respondents ( 30 percent), 53 respondents ( 23 percent) from Johor Bharu, 41 respondents (18 percent) from Kuala Lumpur, 35 respondents (15 percent) from Ipoh, 23 respondents (10 percent) in Kuching and only a small number, 10 respondents (4 percent) were from Kota Bharu.

Table 2. Profile of survey respondents

\begin{tabular}{cll}
\hline & $21-34$ & $74(32 \%)$ \\
Age & $35-54$ & $147(64 \%)$ \\
& 55 and over & $9(4 \%)$ \\
\hline \multirow{3}{*}{ Regional Centres } & Penang & $68(30 \%)$ \\
& Johor Bharu & $53(23 \%)$ \\
& Kuala Lumpur & $41(18 \%)$ \\
& Kuch & $35(15 \%)$ \\
& Kothing Bharu & $23(10 \%)$ \\
& $10(4 \%)$
\end{tabular}


As we have already discussed in this paper regarding surveys conducted across Malaysia many welcome the Ministry's proposal to increase the retirement age, though some might have reservations and concerns about the potential drawbacks when the bill passes into law. Not surprisingly, results from this study also show a very similar result, as indicated in Figure 2. Taking a broader perspective, Figure 3 analysed and represents the cross tabulation of responses according to respective age groups.

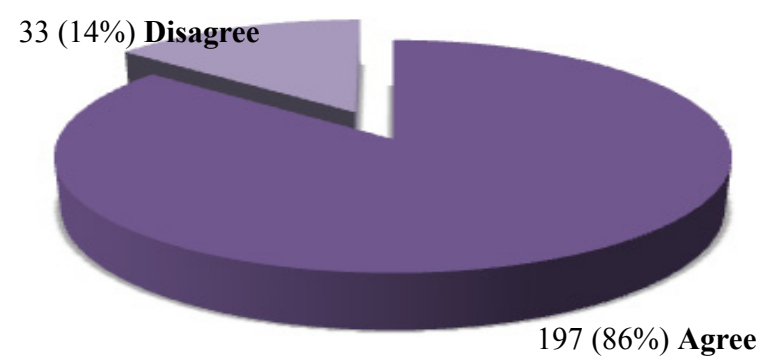

Figure 2. Perceived reaction towards the proposed changes in retirement age to 60 years old (Agree / Disagree)

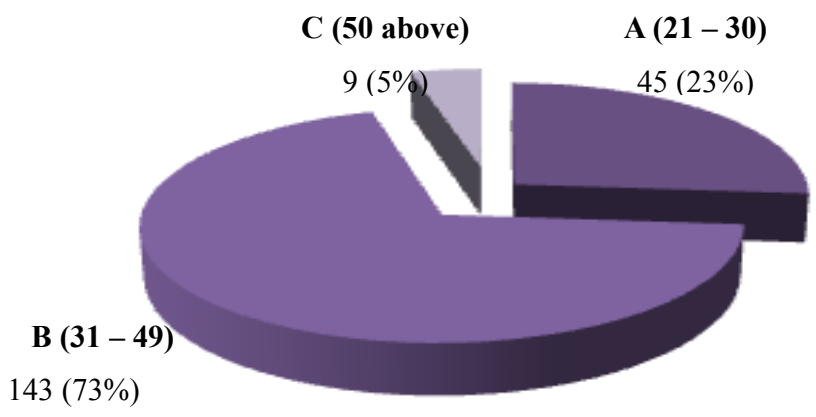

Agree

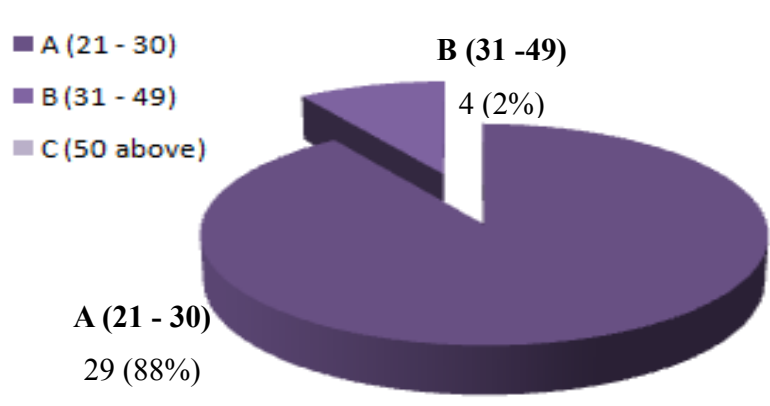

Disagree

Figure 3. Perceived reaction towards the proposed changes in retirement age to 60 years old (Agree / Disagree) by age groups

About $86 \%$ (197) respondents of this study perceived and agreed that the proposed changes in retirement age should increase to 60 years old. Only thirty-three (14\%) respondents reacted differently and disapproved of the change. Nevertheless, this result is consistent with other surveys done by jobstreets.com (Jobstreet.com, 2011) and Brossard and Chatelet (2010) in 2010 and 2011, respectively. Also note that studies in the literature suggested that the general public's opinion was that most welcome the proposed raise of retirement age, however, from the businesses' and employers' standpoints, the issue seen unfavourably (Federation of Malaysian Manufacturers, 2012; HR Matters, 2012). An explanation for why employers may view the proposal unfavourably could be that the cost associated with older (senior) employees, since often older workers have higher salaries than younger employees. When breaking the sample down on the basis of age groups (as shown in figure 2), some additional insights emerge. Comparing respondents aged 50 and over with younger respondents suggests that older respondents are all in favour and all of them who are 50 above agreed with the increase in retirement age. Nearly 73 percent of the mid-age group $(31-49)$ agreed with retirement age change. People who are in the mid-age group seem to see value and the need to revise the retirement age, as most of them are either in their career peak and retirement planning may be one of the factors they are thinking about. These findings perhaps mirror the findings from a survey which was conducted by ING Insurance Dashboard in 2011 with data collected through involved online interviews with 2,300 Malaysian who were in their mid-career. This group reported that they were most concerned about retirement planning for their own protection and that of their family (Teo, 2011). Other interesting findings from this study suggested that young respondents (especially aged 21 to 30 years) and who are either still in school or in their early career think that the move to increase retirement age might not be a good idea. Pak (2011) interviewed both old and young Malaysians on the similar issue. The older respondents might seemed optimistic about the move, but also found the proposal worried some young Malaysians. The author shared that many young Malaysian are pessimistic and worry 
whether the higher retirement age will affect their job prospects and whether it might prevent advancement in their company.

Respondents to this present survey were also asked to assess benefits and potential drawbacks in an open-ended format. The researchers then coded respondents responses into four common themes and dimensions of concerns (demographically-concerned, economically-concerned, socially-concerned and politically-concerned). Following is the detailed analysis:

\subsection{Demographically-concerned}

Many respondents noted that the current life expectancy for Malaysian has greatly improved for the past 20 years, with the average Malaysian who reaches 55 years old still being healthy. The presumed increases longer life expectancy and health also means better stamina for older people to carry on with their work and career. Several respondents noted that with the better quality of health people who are in their retiring age are able to work longer. Other respondents commented that older employees have a significant role in an organisation especially due to the wealth of knowledge from the longer working lifetime and experience, it is an underused valuable asset to an organisation that would continue to contribute greatly to help train younger workers through the transfer knowledge and experience. In one particular respondent offer that:

"According to the research, the current Malaysian is 71 years old for men in 2000 and 75 years old in 2025. Hence, longer life of expectancy and better health and higher quality of life and the older people can continue working longer. The retirement age of 55 at the private sector is outdated and set at a time when the life expectancy age was considerably lower which is lower than 55 for men in the 1950s. I think that Malaysians are still capable after 55 to continue working and contributing to Malaysia's productivity and development. There are about a twenty year gap for individuals to support themselves without an income if they retire at 55."

Although many respondents see that older workers's vast knowledge is actually an added asset to the country's development, as with the early retirement policy, the Malaysian government might have to train more young people to fill up the gap left by the senior workers which would be quite costly and time consuming to the nation (in the long haul). In particular one respondent use the quoted from Malaysian Mirror the Cuepacs president 'it is a waste to train a person up to a high level and then let them go early'. Other respondents shared the view that by retaining more older workers in the workforce would reduce chances of finding work or advancing for younger Malaysian. Attendant to this is the risk of young Malaysians leaving the country for better career opportunities, contributing to the phenomenon often called "brain drain". One respondent expressed that:

"In the mean time we faced a high unemployment rate among graduates. Graduates number keep on increasing each year, however with the limited job opportunity, the younger generation can't stand a chance compared to the senior staff. The employment cycle is similar with the cycle of life. Each day there is numerous numbers of deaths and they will be replacing by newborns to balance the cycle of life. However, what if the death rate is not proportion to the newborn rate? This aspect also applies to the employment cycle. If there is no enough vacancy to fill the need of the ever increase rate of fresh graduates, graduates will look for the option of migration to other country. In the long term, Malaysia will face larger problems due to their decisions to extent the retirement age. The 'brain drain' phenomenon will cause lack of human capital in the nearest future."

Several respondents (especially the younger respondents) were not very thrilled by the issue, in fact, one particular respondent commented that "... if the government rise(s) the retirement age where there will be higher demand for young people like us to get job if this new changes being implemented". While other respondents indicated if the older (senior) workers are still around in an organisation the junior staff will not be able to get promoted in the near future. The presumption was that young worker has to wait longer to get career advancement (promotion) in an organisation.

\subsection{Economically-concerned}

In terms of the economic aspects, many respondents commented that the advantage to extending the retirement age would contribute immensely to domestic demand and gross domestic product (GDP). Many quoted studies that have show increasing retirement age by 5 years would increase the GDP growth by $0.2 \%$ per year. Thus, a direct impact to the economy would be the benefits gained from older employees' skills and experience as well as their increased purchasing power. One respondent in particular commented that:

"Malaysia currently losses about 400,000 employees a year due to this implied retirement age in the private sector. It is apparent that these 400,000 employees could have a considerable effect on the GDP growth and the private sector maintaining retirement age at 55 is an overlooked opportunity for increasing the GDP growth rate to the high target of $6 \%$ in the 10th Malaysian Plan." 
Other respondents also noted that a prolonged working life helps ensure that older employees have adequate retirement savings when they are do retire. Many respondents claimed that those who withdraw their EPF savings often run out of money within four years of retirement. However, if the retirement age is increased to 60 years this can severely reduce the pressure to increase EPF contribution rates. Other respondents see that increasing the retirement age would help older people to cope with higher costs of living which can cause many retirees to not be able to continue supporting their family. Some of the comments in this line of thinking are as follows:

"The reason behind the increase of retirement age is due to the concern of community toward the standard of living in Malaysia. They feared that their saving for retirement is insufficient to support them after the retirement as the consequence of the increase in standard of living in Malaysia. Through the increase in age of retirement, it believes to be a great assist to the staff to boost more saving for their retirement. They (public and civic workers who work under the government) will also gain advantage in term of service pension, service gratuity or cash award in lien of leaner. Besides, it can benefit parents that still have to support their young children which are still studying."

"Besides that, with the Employees Provident Fund (EPF) contribution, more money can be save and can be use during pensioning or as consistent income for old ages."

"Though Malaysian who work in private sector has a mandatory retirement saving scheme, this was merely enough to cover their retirement age as most of them do not have any other saving. Hence, raising the retirement age to 60 may boost their saving."

Others see rising the retirement age as a way of reducing reliance on foreign workers in Malaysia. Respondents indicated that, "With the proposed new retirement age, we can make more optimum use of local human resources which will subsequently reduce over dependence on foreign workers". One of the examples illustrated from one of the respondents was the example of looking at Singapore's Changi Airport which is efficiently maintained by Singaporean older workers in their late fifties and early sixties while Malaysia's KLIA is flooded with foreign unskilled workers. A few respondents noted that in heavy industries such as car manufacturing industries, employees retiring at the age of 55 are considered as a loss, in the matter of fact, as the Company needs to advertise for new vacancy, interviewing of potential candidates, training and orientation of new recruit, placement of new staff, acquisition of new protective clothing and all these cost are additional expenses to the company. Another participant offered valuable reflections:

"The older employees could offer the option for job rotation which in term would help to promote existing employee within the company to fill a vacancy as the company could cut down the cost on employment through job advertisement and etc"

On the potential economic drawbacks: some respondents noted there is a potential higher cost to company in terms of salaries and employees' protection plans, where older workers usually have much higher salaries and presumably serve to increase costs of employee's protection plan premiums than the younger employees. In particular, one respondent expressed the concerned that:

"Senior staff may cause organisation to pay more for their salary due to their experience compare to the younger generation or junior staff. Instead of paying a high salary for senior staff, the funds can be used to employ a few more personnel. For example, a senior executive with the pay of RM 4000 can be replacing with 2 junior executive for RM 2000 salary each. It is true that skills can be developed through experience. However, it is not necessary a young personnel does not have the ability similar to the senior personnel. A young staff may have more energetic and fresh initiative than a senior staff which can contribute to the progress of an organisation in comparison to the senior."

One participant made a particularly strong claim to discourage of raise in retirement age policy due to the reason of higher paid salary for older employees than to the younger peers, stating that:

"The whole salary package which includes bonus, allowance, and overtime pay are higher for older staff. If the company wants to cut cost, they will want to retire the older staff at the age of 55 and hire new staff at half the cost. The company can even repackage the remuneration deal to suit their budget whereas for the older staff their remuneration package has already been agreed upon many years ago and could be much higher than the new remuneration package."

\subsection{Socially-concerned}

Socially concerned respondents noted that the increase in retirement age for older people may help them to live more independently for a longer period of time. Financial self-support and independence is essential for elderly 
people who are left by their family members after retirement. Other respondents see the extension of retirement age will help an older person to keep social contact with peers (in the workplace) which is beneficial for them. Interacting with other people at the workplace may help prevent elderly people becoming depressed and feeling lonely. As quoted from one respondent response that "...I think with the change to the new retirement age to 60, it will also reduce rate of the health problem among the people in the range of 55 to 60 . Because when people have their own task to do, their life will be more meaningful. They will not think pessimistic. Working provides opportunities for them to deals with many others people as they will feel lonely after retired. Working will face difficulties can train their brain functioned". Along the similar line of thought, one respondent noted that:

"Staying sharp on the job will help to stay fit and healthy. Those who retire early often become sedentary sooner and as a result, this will develop health problems."

While other respondents see issues that may well be tied with the types of occupations and social status. For instance, for a low income blue-collar workers who are required to do more physically demanding work and potentially exposed to hazardous substances tends to have a lower life expectancy than much affluent professional white-collar workers. The increase of retirement age policy might not seen benefits for blue-collar workers where the wages they received might not be adequate for proper nutritions nor for maintaining good health for prolong working years. One respondent pointed out that:

"they enjoyed their work more and received well salary; therefore they do not mind working longer. For that reason, increasing the retirement age can benefit office employees more than labor workers in terms of their standard of living".

Some respondents raise the concern, and see that the extended retirement age, would create a generation gap problem especially in the work environment. For instance, with different living style, changing of environment and also the difference education timeframes could be elements contributing to conflict between the young and old (senior) employees. In particularly, one respondent offered:

"The older generation would also be stuck in their own ways, it would be hard for them to adapt to new change and new concepts that the firm may change. They would be stubborn and set in their ways. Thus making it difficult for management to change policies, improve and enhance policies, concepts and perhaps business processes."

Some respondents see productivity as another issue and fear that older employees may not be able to keep up. The senior employees may have lower productivity as they may be more likely to encounter health issues at the older age. The lack of stamina or health problems encountered by older employees will also cause difficulties to the organisation. Several respondents noted that older employees may not have the same capabilities as the younger generation in terms of catching up with the ever changing new technology. The younger generation would be more proficient and faster at picking up the ever changing new technology than older generation. It was also noted that many young respondents make a pursuasive argument that with the raise in retirement age, the opportunities for attaining career advancement are reduced because they may have to wait additional years to attain better positions in the organisation when older workers retire. This may result in the younger people migrating to other countries for better job opportunities. One the respondent wrote that:

"One of the most important disadvantages of increasing retirement age is that the job opportunities for young people may decrease. Many firms reduce their hiring of young workers due to they are lacking of experience and skills compare to the senior workers and this has give impact to the unemployment rate of fresh graduates and younger people."

Some concerns where expressed on the age discrimination phenomenon where older workers could face bias from employers who prefer younger employees with newer skills and smaller salaries especially in this econimic uncertainty. One in particular respondent share that "....recent recession has seen laid-off workers in their 50s and 60s spend more time unemployed, with many worrying they may never work again or will have to take pay cuts that will diminish what they eventually collect from Social Security benefits."

\subsection{Politically-concerned}

In the governmental sector, some respondents shared that extending the retirement age will provide a solution to problems of renewing contract for certain portfolios and this opens up opportunities for promotion for other civil servants to move up the ranks to hold higher positions. As one the respondent wrote in the comments: "...no more stifling of promotion or renewing of service because everyone will retire at the same age at 60 years..." Similarly, one respondent offered the comment that: 
"Longer services meant more money require to pay wages, health care, insurance due to higher life expectancy. When Government is forced to spend more on wages etc, its need to borrow money if the coffer of the Government is small and thus will raise the inflation rate. So when inflation rises, the cost of basic staples also rise and consequently Government will need to increase subsidies otherwise the local population such as farmers, fisherman and others who had no stable income will suffer. When the people suffer, they tend to go against the Government which eventually will cause the fall of the Government..."

Still, some respondents think that the government agencies are the ones that are advocating the raise of retirement age policy. Respondents noted that longer working years will be able to boost public finance through increased in tax collection when people work longer indirectly means that they need to pay the taxes longer. As the new retirement age is expected to retain 500,000 people in the workforce over a five years period, this on the other hand is also enabling the government to have 500,000 people to continue paying taxes for at least another 5 years period to contribute to the public finances. Several participants also shared that the new proposed change would help in reducing the cost of pension and the burden on governments to provide healthcare and old age welfare. As the average life expectancy of Malaysian has increased to about 74 years old, this means that people who retire at the age of 55 will depend on governments' support for about 20 years in the old retirement scheme. The lifted retirement age, ultimately, will ease government spending. One respondent seems to believe that as for the government, government will have to double the effort to create jobs opportunities because the increments in retirement age policy will potentially decreased job opportunity for fresh school leavers and new graduates. Government has to compete with other countries to attract foreign investor to invest in this country. With the stiff competition from other Asian countries, especially China, Indonesia and Vietnam who could provide cheaper workforce, the task would be difficult.

\subsection{Summative of These Four Dimensions}

A summative of the findings of the received comments from the respondents was recorded in the following Table 2. The table is divided into two respectively columns, benefits (support) and drawback (against), in summarising the recorded answer scripts from the respondents on their perceived of the effect of propose rising in retirement age policy as their reflected on their own retirement.

Table 2. Respondents perceived benefits and drawbacks

\begin{tabular}{|c|c|c|}
\hline & Benefits (Support) & Drawbacks (Against) \\
\hline \multirow{3}{*}{ Demographical-concern } & $\begin{array}{l}\text { a) Due to better health and } \\
\text { raise in life expectancy, } \\
\text { present senior workers are in a } \\
\text { better stamina and higher } \\
\text { quality of life than their parent } \\
\text { generation. }\end{array}$ & $\begin{array}{l}\text { a) Retaining senior (older) } \\
\text { workers might reduce the } \\
\text { chances for younger } \\
\text { Malaysian finding work in } \\
\text { present scarce career } \\
\text { opportunities. }\end{array}$ \\
\hline & \multirow{2}{*}{$\begin{array}{l}\text { b) Contribution and pass-on } \\
\text { the wealth of knowledge to the } \\
\text { younger generation. } \\
\text { c) Filling the vacancy gap } \\
\text { might be too costly (i.e. } \\
\text { training the young generation } \\
\text { for replacement) }\end{array}$} & $\begin{array}{l}\text { b) Some fears of posting } \\
\text { obstacles in career } \\
\text { advancement, especially for } \\
\text { younger workers (who are } \\
\text { in their mid-career). }\end{array}$ \\
\hline & & $\begin{array}{l}\text { d) Potentially leads to } \\
\text { "brain drain" phenomenon } \\
\text { of the young professional } \\
\text { choose to leave for better } \\
\text { career advancement in } \\
\text { other countries. }\end{array}$ \\
\hline \multirow[t]{2}{*}{ Economically-concern } & $\begin{array}{l}\text { a) Contribution to the growth } \\
\text { of domestic demand and gross } \\
\text { domestic product (GDP) by at } \\
\text { least } 0.2 \% \text { per year. }\end{array}$ & \multirow{2}{*}{$\begin{array}{l}\text { a) Higher cost for retaining } \\
\text { senior (older) workers than } \\
\text { to the younger workers (i.e. } \\
\text { salary, employee's } \\
\text { protection premiums). } \\
\text { b) Some argument on }\end{array}$} \\
\hline & $\begin{array}{l}\text { b) Ensure adequate retirement } \\
\text { savings (for some). For }\end{array}$ & \\
\hline
\end{tabular}




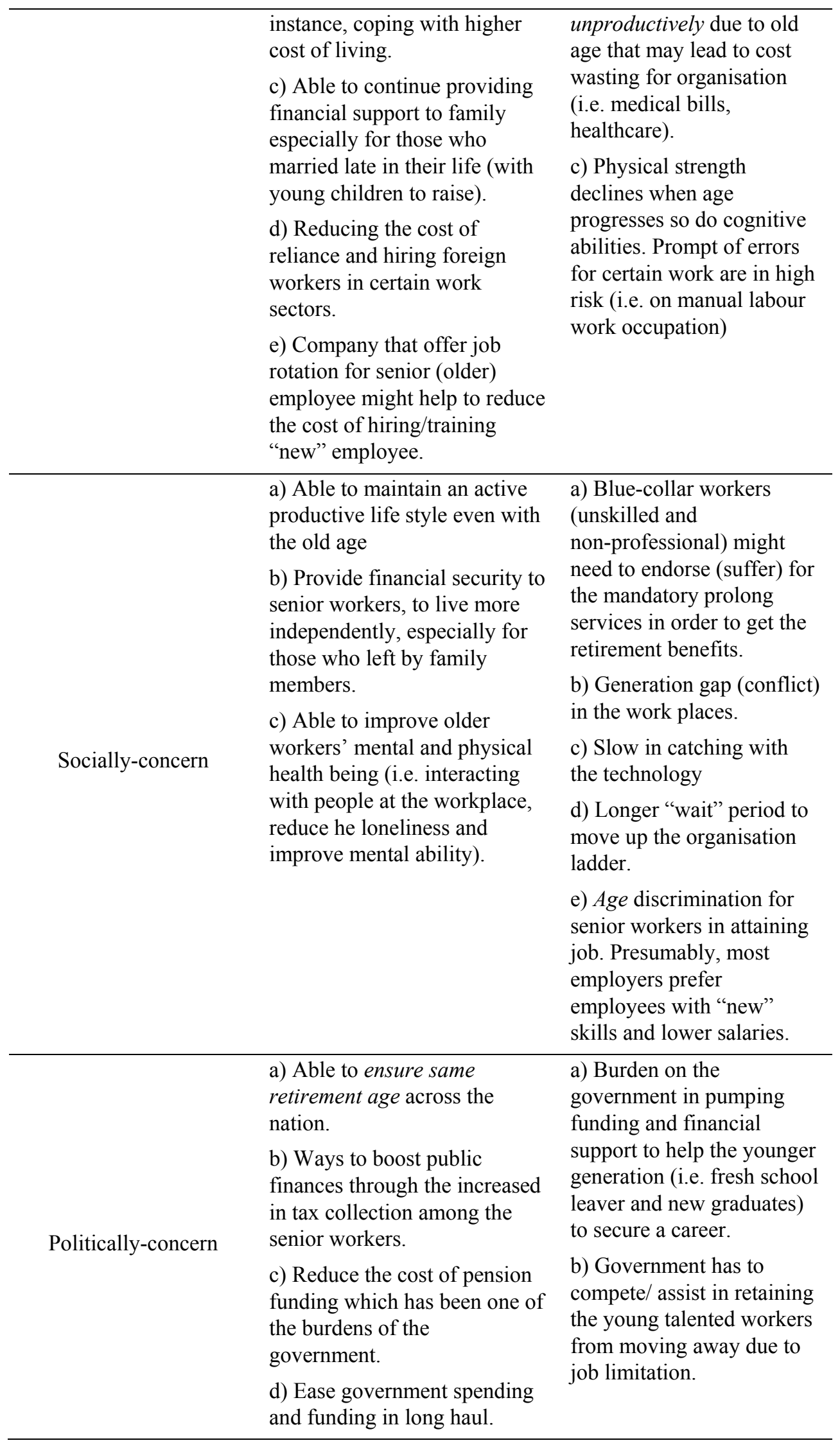




\section{Implications for Human Resource Management}

The fastest growing segment of population in the next two decades, according to International Development Research Center (IDRC), is the elderly group. The Census showed that $9.5 \%$ of Malaysians are those aged 60 and above. This is an increase from the 2000 census, where group represented $6.2 \%$ of the population. The younger generation, however, seems to be decreasing as a proportion of the population while that of the elderly is rising. The old age dependency ratio has increased as the proportion of the elderly is rising (Ong, 2002). What are the implications of these trends for long range human resource management? Human capital planners need to begin thinking of potential remedies now, while there is sufficient lead time to make the necessary adjustments to current retirement policies.

Being a developing country, Malaysia needs a vibrant labour force to contribute to the productivity of the nation. The higher the ratio of old age dependency, the higher the pressure on a nation's budget as the government needs to spend more on the dependency group. When workers work longer, it can remove some of the pressure on the government, but does that come at the expense of younger workers and younger workers opportunities? As this study result has shown that, in general, younger Malaysians are the ones that fear and feel the most uneasy because of the raise of retirement age. Is it possible to reach a point where "age" is generally seen as a good thing, which benefits enterprises or the nation as a whole? Older workers are often believed to be more reliable, more committed and more loyal to the organisation. They may have good interpersonal skills, experience and competences that they can share, so preventing knowledge gaps when they retire as compare to the younger workers (Lazazzara and Bombeli, 2011). There is also a possibility that the young adults (who are in their early twenties) in this research study as they move on into their thirties that their attitude towards this issue will change and they will be more receptive to the later retirement idea. No doubt that the fears and resistants for the change might be due to the "misconception" of the scarcity of job opportunity in Malaysia, and without the retirement of the older workers, companies are not in the position to accept new applicants. Wye and Ismail (2012) study noted that the opposite effect where the researchers examines the sources of labour productivity growth in Malaysian major economic sectors using annual time-series data from Malaysia Economic Statistic, and their results show that overall both capital-labour ratio and quantity of labour are positive with no significant sign of job scarcities, despite most would anticipated this because of global meltdown an financial crisis in the European nation. Teo (2011) noted, according to the survey by top online recruitment firm reported, that most employers said young workers and fresh graduates had "unrealistic expectations" of salaries where jobless graduates were overly stressed on the remuneration package and rejecting jobs which they considered lower-class occupations. While other top factors for the unemployment for young Malaysian adults were due to poor performance in English command and bad attitudes. Some respondents of this study indicated that age are inverted related to job performance, as age increase the performance and productivity may decrease. These claimed was revoked by studies done by Knapp and Muller (2000) and McEvoy and Cascio (1989) who found that age and job performance did not, in fact, have the "assumed" claim inverted-relationship, both their studies demonstrated that productivity for older workers does not actually decline when age progresses. Older workers in most fields especially in work that does not require physical work can keep pace with their younger peers and are not out sick any more than young people (Knowledge Warton, 2010). Other studies also indicated that older workers are more likely to stay with an organisation and young people tend to move around more for job advancement and that caused more loses to the organisation (Bastien, 2006). With increasing life expectancies, more senior employees will feel mentally and physically able to extend their careers, the move to rise the retirement age, in general, are seen as positive across the respondents of this study. Though it might be too soon to "predict" the outcome of the proposal for the change in the retirement age, nevertheless, it is fairly important for human resource practitioners and all the involved parties to begin assessing the readiness of organisations (public or private) to embrace the policies encouraging older employees to postpone their retirement. Human resource practitioners and involved parties should begin to look into training-based approaches to manage and develop older workers through continuous learning that can retain and motivate older workers; enhance the employability of senior employees; and maintain skill levels within the organisation from a human resource perspective. A wide range of alternative career options are available for consideration, for instance, initiating job sharing option for senior employees where job sharing allows two or more employees to divide duties and responsibilities of a job and enjoy reduced work schedules for much lower pay schemes that benefits the older employees and the employer. As most respondents of this study agreed upon senior (older) employees are valued for their vast experiences, with the changing role of senior employees into consulting or mentoring roles would capitalise on their experiences at the same time permits greater scheduling flexibility, is another alternative approach from a human resources standpoint. The contention is that pairing experienced senior employees with younger employees in mentor 
relationships create opportunities for capitalising on senior employees' expertise and contacts, which ultimately would helps the transition process. Alternative approaches such as re-engaging retirees on yearly basis contract can be consider and applicable to high ranking employees who are scarce in their fields of work and high where there is a demand for their expertise and experiences. Other scheme and option that can be a considered as propose in the Singaporean Ministry of Manpower of introducing the "Retirement and Re-employment" policy, instead of merely raising retirement age beyond the current 58 years old. The flexibility option helps older workers, who are willing and able to continue working, to do so beyond retirement and thus provide flexibility to facilitate employers to retain their older workers beyond retirement.

\section{Conclusion}

The retirement policies in the 21 st century must withstand the ever-changing socio-demographic movements. It is time to re-examine those policies in order to fit the realities of the new demographic era of people living longer. The Ministry of Human Resource of Malaysia's proposed a new bill to make 60 years the earliest retirement age for Malaysians. This will perhaps be a turning point in the new decade, fostering new retirement strategies and policies. However, collective efforts must come from all involved parties: government, employers, workers, and others to create a vibrant and progressive 'silver' society and economy where wisdom and experience are valued to move Malaysia into a high income nation. In analysing the policy, the ideal comparison can be made between the France and Malaysia. The change in policy in countries like France is driven by two main factors: the financial cost of early retirement; and the shrinking pool of new workers who can replace them. On the other hand, the demographics in Malaysia do not reflect the same reality. Figure 4 in illustrates the comparison between these two countries. In France, as can be seen in left side of Figure 4, the population coming up to replace the present working population is smaller than the older population. The delayed working age will help ensure the needed working force. Conversely, in Malaysia the demographics are completely different.

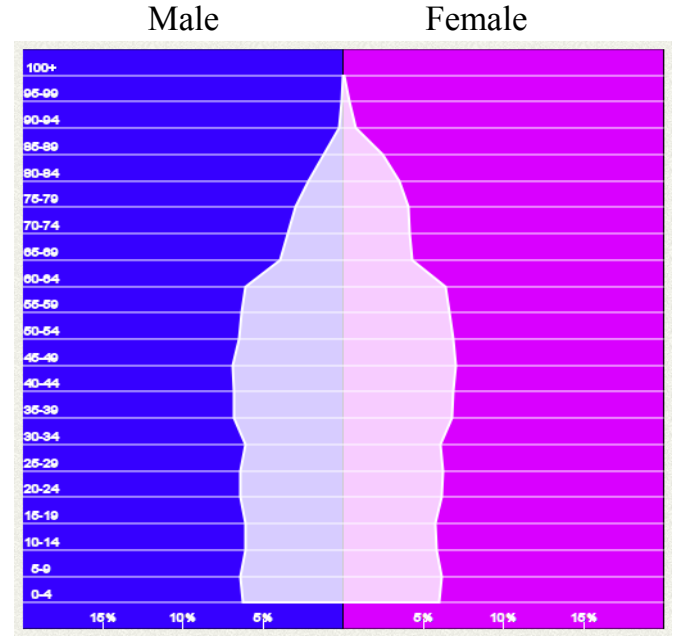

France Year 2010

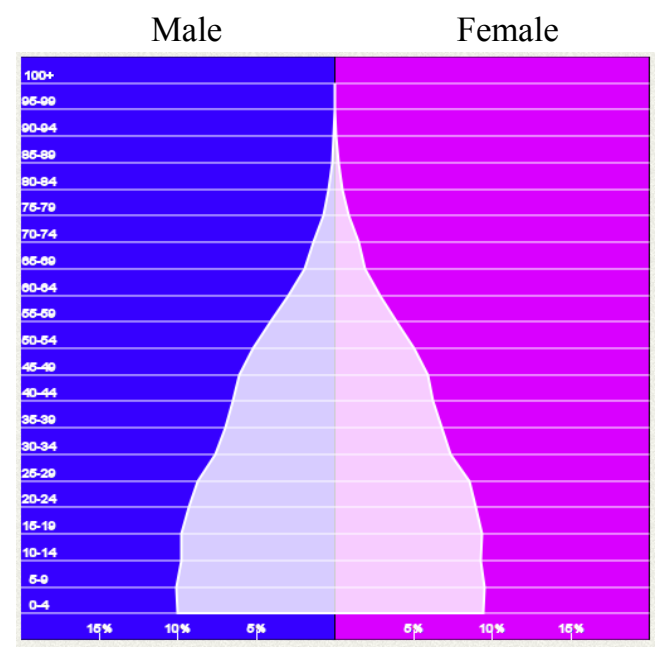

Malavsia Year 2010

Figure 4. Comparison between the France and Malaysia population scenario (graphical table taken from worldlifeexpectancy.com)

Malaysia has a large pool of younger people who will enter the workforce. Late retirement will mean less existing jobs openings for them which will bring about new challenges. Both the government and the industries have their own challenges in creating employment for this imposing group of young people entering the job market. We can also infer that competition for available jobs will be more intense and this does reflect a pre-occupation that was expressed in the survey. This intense competition may just require the Educational Institutions to enter into a new challenge in preparing this new work force to be better able to compete in the job market. Ultimately, the new challenges will also arise in Human Resource Management. Our survey results indicated a potential conflict between older and younger workers. Resource management may have to find new ways of managing an older workforce while at the same time integrating new ideas and skills in the work place. 
In summary, though this study cannot be generalise nor can the results fully representing the collective opinions across all Malaysian on such a topic, yet this study was able to show that there are numerous dimension of concerned from demographically, economically, socially and politically points of views that Malaysians, across five major cities, would like to be given the opportunity to have their voice heard. With eighty-six (86\%) percent respondents agreeing on the proposed retirement age (in this study), clearly, perhaps it is the right time and right place, for examining the current retirement policy for betterment of the nation and so in line with nation plan aiming to be a high-income nation in the not so distant future.

\section{References}

Applebaum, S. H., Patton, E., \& Shapiro, B. (2003). The early retirement incentive program: a downsizing strategy. Journal of European Industrial Training, 27(1), 22-35. http://dx.doi.org/10.1108/03090590310456500

Bastien, S. (2006). 12 benefits of hiring older workers. Retrieved from http://entrepreneur.com/article/167500

Beehr, T.A. (1986). The process of retirement: a review and recommendations for future investigation. Personnel Psychology, 39, 31-55. http://dx.doi.org/10.1111/j.1744-6570.1986.tb00573.x

Brossard, M., \& Chatelet, F. (2010). AXA Retirement Scope 20120 - Malaysia report. Retrieved from http://www.axaaffin.com/viewdownload.aspx?file=117fi_990.pdf\&ofile=AXA+Retirement+Scope+2010+ Malaysia+Report.pdf

Casey, B. (1998). Incentives and disincentive to early and late retirement. OECD, Retrieved from http://www.oecd.org/dataoecd/22/5/2428694.pdf

Central Intelligence Agency (2012). The World Factbook, Retrieved from https://www.cia.gov/library/publications/the-world-factbook

Department of Statistics Malaysia (August, 2010). Demographic Indicators, Retrieved from http://statistics.gov.my/portal/download_Population/download.php?file=BPD/ind_2010.pdf

Federation of Malaysian Manufacturers FMM (2012). Manufacturers Expecting Better Outlook. Retrieved from http://www.fmm.org.my/Press_Releases-@-Manufacturers_Expecting_Better_Outlook.aspx

Fujioka, C. (2008). Japanese workers more unhappy, government report says. Reuters, Retrieved from http://uk.reuters.com/article/2008/07/22/us-japan-labour-idUKT30904520080722

Gendron, B. (2011). Older workers and active ageing in France: the changing early retirement and company approach. The International Journal of Human Resource Management. 22(6), 1221-1231. http://dx.doi.org/10.1080/09585192.2011.559095

HR Matters (2012). Hot topic Survey -Minimum wage and mandatory retirement age for the private sector. Retrieved

from http://www.hr-matters.info/news2012/HotTopic\%220SurveyMinimumWageAndMandatoryRetirementAge ForPrivateSector.html

HSBC's The Future of Retirement report (2011). Future of Retirement Family Matter, Retrieved from http://www.hsbc.com/1/2/retirement/for-family-matters

Jobstreet.com (2011). Malaysian Jobseekers Want Retirement Age Raised but Fear Impact, Retrieved from http://www.jobstreet.com.my/aboutus/preleases161.html

Knapp, K., \& Muller, C. (2000). Productive lives: Paid and unpaid productive activities of older Americans, Research Report, NY: International Longevity Center, USA.

Knowledge Wharton. (2010). The 'Silver Tsunami': Why Older Workers Offer Better Value Than Younger Ones, Retrieved from http://knowledge. wharton.upenn.edu/article.cfm?articleid=2644

Lazazzara, A., \& Bombeli, M.C. (2011). HRM practices for ageing Italian workforce: the role of training. Journal of European Industrial Training. 35(8), 808-825. http://dx.doi.org/10.1108/03090591111168339.

McEvory, G. M., \& Cascio, W.F. (1989). Cumulative evidence of the relationship between employee age and job performance. Journal of Applied Psychology, 74,11-17. http://dx.doi.org/10.1037/0021-9010.74.1.11

Miles, M. B., \& Huberman, A. M. (1994). Qualitative data analysis: An expanded source book (2nd ed.). Thousand Oaks, CA: Sage. 
Ministry of Manpower (2011). Retirement Age (Amendment) Bill 2011 2nd Reading Speech by Mr Gan Kim Yong, Minister for Manpower. Retrieved from hattp://www.mom.gov.sg/newsroom/Pages/SpeechesDetail. http://www.mom.gov.sg/newsroom/Pages/SpeechesDetail.aspx?listid=308

$\begin{array}{lll}\text { MyGoverment } & \text { (n.d.). } & \text { Retrieved }\end{array}$ http://www.malaysia.gov.my/EN/Relevant\%20Topics/Employment\%20and\%20Training/Citizen/Retireme nt/Pages/RetirementMain.aspx

Ong, F.S. (2002). Ageing and long-term care: National policies in the Asia-Pacific. International Development Research Center. Retrieved from http://web.idrc.ca/en/ev-28476-1-DO TOPIC.html

Pak, J. (October, 2011). Malaysia to raise retirement age to 60. BBC News Business. Retrieved from http://www.bbc.co.uk/news/business-15162907

Rosen, B., \& Jerdee, T.H. (1986). Retirement policies for 21st century. Human Resource Management, 25(2), 405-420. http://dx.doi.org/10.1002/hrm.3930250306

Teo, A. (September 2011). ING Survey: retirement planning top of Malaysian's concerns. The Edge. Retrieved from

http://www.theedgemalaysia.com/personal-finance/193259-ing-survey-retirement-planning-top-of-malaysi ans-concerns.html

Teoh, S. (2011, July 30). Malaysian graduates struggle to get good jobs, says Straits Times. The Malaysian Insider.

Retrieved

from http://www.themalaysianinsider.com/malaysia/article/malaysian-graduates-struggle-to-get-good-jobs-saysstraits-times

Teoh, S. (2012, June 1). Bill tabled for private sector minimum retirement age. The Malaysian Insider. Retrieved from http://www.themalaysianinsider.com/malaysia/article/bill-tabled-for-private-sector-minimum-retirement-ag e-of-60

Turners, J. A. (2008). Work Options for Older Americans: employee benefits for the era of living longer. Benefits Quarterly, third quarter, 20-25.

Wye, C.K., \& Ismail, R. (2012). Sources of Labour Productivity Growth by Economic Sectors: A study of Malaysia 1972-2005. International Journal of Management, 29(2), 760-777. 